\title{
A Revista Científica do Hospital Santa Izabel
}

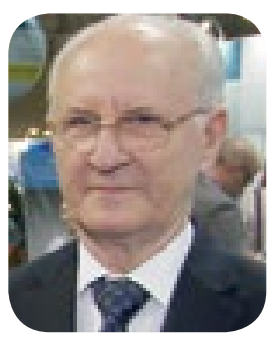

A Revista Científica do Hospital Santa Izabel existe com o propósito de apresentar aos presentes, assim como deixar como legado para as gerações futuras, o conhecimento da ciência da saúde como entendido pelos que vivem o cotidiano atual da nossa instituição, por meio de: a) artigos de revisão contemporânea de aspectos nosológicos; b) documentação de artigos originais produzidos pela comunidade científica do $\mathrm{HSI}$ e publicados em revistas indexadas em bases nacionais e internacionais; c) relato de casos especiais vivenciados em nosso hospital.

Tratando-se de ser, como é o caso do Hospital Santa Izabel, um Hospital de Ensino reconhecido pelo Ministério da Saúde e pelo Ministério da Educação, é mister que assim o faça, com a participação editorial de todos os que compõem a comissão de residência médica e de residência multiprofissional da saúde do HSI e colaboração de todos os que aqui atuam e geram conhecimento.

O projeto da Revista Científica do Hospital Santa Izabel vinha sendo acalentado há muitos anos e vem sendo executado há 3 anos.

Tendo em vista sua projetada importância, planejou-se sua implantação de maneira muito cuidadosa, com a clara compreensão de que seu propósito é de ser perene, regular, confiável e acreditado por todos.

Muitos têm sido os periódicos que pecam em sua execução pela falta de uma cuidadosa observação dos preceitos que possibilitam atingir os propósitos grandiosos que os originam. Assim se tornam inconstantes, irregulares, desacreditados e de curta sobrevivência.

A nossa revista, já existente há 3 anos, demonstra uma firmeza de cumprimento de propósitos, haja vista sua publicação sem falhas e nem mesmo atrasos, nos 3 anos prévios.

Isso confirma a existência entre nós de uma adequada massa crítica de conhecimento científico, envolvendo vários setores, que fazem pulsar o nosso hospital e que garantem sua característica e fazem prever sua longevidade e crescimento.

Tudo isso tornou-se possível porque, ao longo dos anos, constatou-se a criação de serviços com protocolos elaborados e executados à máxima perfeição possível.

\author{
Gilson Soares Feitosa ${ }^{1}$
}

Garantiu-se assim uma prática assistencial, base fundamental das ações de saúde, que fornecesse ao HSI uma credibilidade interna e externa de excelência.

Avançou-se no campo formador de médicos e de outros profissionais da saúde em bases sólidas e reputáveis. O projeto é incentivado pela alta gestão da Santa Casa da Bahia e pelo corpo diretivo do HSI. Agora, que completamos 3 anos de existência, maior ainda a motivação para darmos continuidade a essa obra!!

Vamos traduzir em material impresso toda a energia contagiante que se irradia no dia a dia das atividades do nosso hospital.

Nessa amálgama de semblantes sérios, compenetrados, mas também solícitos, sorridentes, corteses, que se veem em nossos corredores, enfermarias, centros cirúrgicos, centros de apoio diagnóstico e terapêutico, numa profusão de ações que se complementam em prol do paciente, o Hospital Santa Izabel se transformou no desenrolar de sua longa existência num complexo nosocomial de grande espectro de atuação, atendendo a todas as exigências de complexidade que o nosso momento atual impõe.

Sua incessante procura de qualidade e humanismo tem atraído profissionais de grande estirpe em todas as áreas de atendimento à saúde e, particularmente, no setor médico, tem sido capaz de gerar e renovar seus quadros.

Todo esse conjunto necessariamente condiciona o desenvolvimento de aparelho criador de conhecimento e sua conveniente aplicação.

No que se traduz pelo número de comunicações, trabalhos e ações institucionais que repercutem extramuros.

A Revista Científica do Hospital Santa Izabel procurará documentar essas ações.

1- Editor da Revista Científica do HSI

Endereço para correspondência:

gfeitosa@cardiol.br 